\title{
Effects of Faba Bean (Vicia faba L.) Flour on Viability of Probiotic Bacteria During Kefir Storage
}

\author{
Souhila Boudjou ${ }^{1}$, Farid Zaidi ${ }^{1}$, Farah Hosseinian ${ }^{2,3}$ \& B. Dave Oomah ${ }^{4}$ \\ ${ }^{1}$ Université Abderahman Mira, Béjaia, Route Targa Ouzemour, Béjaia 06000, Algeria \\ ${ }^{2}$ Carleton University, Food Science \& Nutrition Program, Chemistry Department, Ottawa, Ontario, Canada K1S \\ 5B6 \\ ${ }^{3}$ Carleton University, Institute of Biochemistry, Ottawa, Ontario, Canada K1S 5B6 \\ ${ }^{4}$ (Retired), Formerly with the National Bioproducts and Bioprocesses Program, Pacific Agri-Food Research \\ Centre, Agriculture and Agri-Food Canada, Summerland, BC, Canada V0H 1Z0
}

Correspondence: Farah Hosseinian, Carleton University, Ottawa, Ontario, Canada. E-mail: farah_hosseinian@carleton.ca

Received: June 3, 2014 Accepted: July 16, 2014 Online Published: July 18, 2014

doi:10.5539/jfr.v3n6p13 URL: http://dx.doi.org/10.5539/jfr.v3n6p13

\begin{abstract}
Whole ground faba bean was investigated for its capability and efficiency to enhance bacterial survival and growth during kefir storage. Microbial analyses, $\mathrm{pH}$ and total titratable acidity (TTA) were measured in kefir samples, containing starter cultures with or without probiotic bacteria, (Lactobacillus acidophilus and Bifidobacterium lactis) supplemented with whole ground faba bean during 28 days cold storage at $4{ }^{\circ} \mathrm{C}$. Faba bean flour supplementation (4\%) stimulated bifidogenic microbial growth, increased titratable acidity linearly from day 1 to 21 , and reduced $\mathrm{pH}$ during kefir storage. Bacterial count was strongly and positively correlated with lactic acid content and inversely associated with $\mathrm{pH}$. Faba bean contributed to the additive effect on viable cell counts and $\mathrm{pH}$ of the probiotic co-culture (Lb. acidophilus and B. lactis), but had a distinct antagonistic effect on titratable acidity of kefir. Hierarchical cluster analysis based on the microbiological, titratable acidity and $\mathrm{pH}$ data differentiated kefir corresponding to the presence or absence of faba bean supplementation. Faba bean flour maintain sprobioticst ability and extends kefir shelf life.
\end{abstract}

Keywords: kefir, faba beans, (Vicia faba L.), probiotics, Lactobacillus acidophilus, Bifidobacterium lactis, co-culture, titratable acidity

\section{Introduction}

Digestive health has been the focus of novel functional food developments with prebiotics leading the trends. In fact, dairy's rebirth as a natural whole food is expected to continue its leading trend in 2014 (Mellentin, 2013). Furthermore, consumption of dairy products is expected to rise $25 \%$ by 2025 in the developing world and the Food and Agricultural Organization is urging governments to subsidize/ include dairy products as part of a balanced diet for fighting malnutrition in countries where the diets of poor people are often starch-or cerealbased and lack diversity (FAO, 2013). Dairy is projected to experience one of the largest increases (19\%) in global and regional consumption per person (Alexandratos \& Bruinsma, 2012). Pulse consumption per person decreased almost by one third from 1961 to 2009 and has or continues to be partly replaced in diets by animal products with increasing affluence and wealth (Keats \& Wiggins, 2014). These dietary changes contribute to life-shortening obesity and major chronic diseases that now burden developed and developing nations.

Several studies have focused on reversing the declining pulse consumption by fortifying dairy products with prebiotic benefits from pulse flours. For example, lentil flour was superior to soy and other pulse ingredients (pea protein, pea fibre, chickpea flour, soy protein concentrate and soy flour) in improving probiotic Lactobacilli growth of yogurt (Zare, Champagne, Simpson, Orsat, \& Boye, 2012). Furthermore, green lentil flour (4\%) supplementation increased microbial growth selectively for yogurts containing probiotic bacteria ( $L b$. acidophilus and B. lactis) during storage for 28 days (Agil, Gaget, Gliwa, Avis, Willmore, \& Hosseinian, 2013). Lower lentil flour supplementation (1-3\%) stimulated the growth of yogurt strains ( $L b$. delbrueckii subsp. Bulgaricus and $S$. thermophiles) with marginal $\mathrm{pH}$ change during 28 days storage (Zare, Boye, Orsat, 
Champagne, \& Simpson, 2011). Pea flour (3\%) supplementation also enhanced microbial populations and acid production after production and 28-day storage of skim milk probiotic (Lb. rhamnosus AD200) fermented beverage (Zare, Boye, Champagne, Orsat, \& Simpson, 2013).

Faba bean is one of the most important winter crops for human consumption in the Middle East and North African (MENA) countries accounting for approximately $25 \%$ of the world production. It has high feeding value and with about $30 \%$ protein is considered to be superior to field peas or other legumes in some areas (Link, Hanafy, Melancia, Jacobsen, \& Jelenić, 2008). Animal studies have shown the potential of faba beans in reducing pathogenesis of gastrointestinal infections and preventing problems affecting gut health primarily due to its carbohydrate constituents -key substrate for microbial fermentation in the gastrointestinal tract (Van der Meulen, Panneman, \& Jansman, 2010; Jasman, van Ball, van der Meulen, \& Smits, 2012). In fact the raffinose family of faba bean oligosaccharides fed to rats is quickly metabolized by inducing high microbial glucosidase and galactosidase activities (Juśkiewicz, Wróblewska, Fertykowski, Zduńczyk, Brzuzan, \& Godycka-Kłos, 2006). These oligosaccharides (raffinose, stachyose and vebascose) and sucrose from faba bean have also been used for sourdough fermentation with Lactobacilli (Teixeira, McNeill, \& Gänzle, 2012).

Kefir, originating in Eurasia where its digestive health benefits have been known for centuries, is an ideal platform to deliver pre-and pro-biotics and complementary diverse dietary protein sources. Consumption of probiotic micro-organisms and/or prebiotic fibres provides health benefits by modulating intestinal host microbiota and constitutes preventive measure and remediation against various infections and intestinal disorders. Furthermore, each probiotics and probiotic health benefit is strain-specific or oligosaccharide specific (Saad, Delattre, Urdaci, Schmitter, \& Bressollier, 2013). Several factors such as food matrix, starter cultures used in the fermented product, probiotic strain/s, and storage can affect the stability and viability of probiotic bacteria (Ishibashi \&Shimamuru, 1993; Iwana, Masuda, Fujisawa, Suzuki, \& Mitsuoka, 1993). Probiotic viability during manufacture and storage is imperative to maintain adequate or above minimum concentration required by regulatory agencies and simultaneously offering the claimed health benefits. We have previously shown that the traditional faba bean (whole seeds and cotyledons) from the Mediterranean dry arid regions exerts high antioxidant activity and can therefore be used as a functional food ingredient (Boudjou, Oomah, Zaidi, \& Hosseinian, 2013). This study aimed at evaluating faba bean supplementation modeled on our green lentil investigation in yogurt (Agil et al., 2013) during storage of kefir with and without probiotic supplementation. Kefir was used as a dairy "old format" probiotic product combined with faba bean (prebiotic) reflecting the complementary nature of diverse bioavailable protein sources that can be adapted to suit the tastes of new geographic markets.

\section{Materials and Methods}

Faba bean (Vicia faba L.) subspecies minor seeds from Merdi Ouamane Wilaya of Bejaia, Algeria, was initially crushed in a traditional stone mill followed by an analytic mill (IKA A11 basic; IKA Werke GmbH \& Co. KG, Staufen, Germany) then sieved (Tap sieve shaker AS 200; Retsch GmbH, Haan, Germany) to pass a $500 \mu \mathrm{m}$ screen. The flour was stored $\left(-20^{\circ} \mathrm{C}\right)$ in sealed plastic bags until use.

\subsection{Kefir Preparation}

The freeze-dried starter kefir culture (kefir-type B-heterofermentative culture-without production of $\mathrm{CO}_{2}$, containing Lb. lantarum and Lb. rhamnosus, Lactoccocus lactis and L. cremoris, and Leuconostoc cremoris, Abiasa Inc., Saint Hyacinthe, Quebec, Canada) and two probiotic cultures: Lb. acidophilus (NRRL B-4495) and B. lactis (NRRL 41405, U.S. Department of Agriculture, Agricultural Research Service Culture Collection, National Center for Agricultural Utilization Research, Peoria, IL) were used in this study. The lyophilized culture was diluted in pasteurized, homogenized ( $3.25 \%$ fat) milk (commercial source in Ottawa, ON), stirred at $85{ }^{\circ} \mathrm{C}$ for $15 \mathrm{~min}$, portioned into sterile conical tubes $\left(50 \mathrm{~mL}\right.$ ), and cooled to $42{ }^{\circ} \mathrm{C}$ (Espírito Santo, Silva, Soares, Anjos, Gioielli, \& Oliveira, 2010). The probiotic cultures, Lb. acidophilus and B. lactis were grown in liquid Man Rogosa Sharpe (MRS) broth at $37^{\circ} \mathrm{C}$ for $24 \mathrm{~h}$, rinsedwithsterile water and diluted to a concentration of appoximately $6.5 \log \mathrm{CFU} / \mathrm{mLwithsterilizedmilk.} \mathrm{The} \mathrm{probioticswereadded} \mathrm{to} \mathrm{the} \mathrm{kefirsampleswithequal}$ volumes of eachbacteria culture or co-culture constituting $2 \mathrm{~mL}$ of the $50 \mathrm{~mL}$ final sample volume. Four treatmentscontainedrawfaba bean flour $(2.0 \mathrm{~g} ; 4 \%, \mathrm{w} / \mathrm{v})$ and the remaining four served as controls without faba bean (Table 1). This concentration of faba bean was chosen based on our previous study with green lentil supplementation of yogurt (Agil et al., 2013). The inoculated milk samples were prepared in triplicate, incubated at $42{ }^{\circ} \mathrm{C}$ (Thermo scientific, MAXQ 4450) until completion (about $8 \mathrm{~h}$ ) of fermentation at pH 4.2 and stored at $4{ }^{\circ} \mathrm{C}$ (Agil et al., 2013). All kefirsamplesconsisted of starter cultures and one or bothprobiotics (Table 1) with final probioticcounts of 7.2 and $7.0 \log \mathrm{CFU} / \mathrm{mL}$, respectively. 
Table 1. Experimental design to evaluate the effect of fababean addition on kefir

\begin{tabular}{lcl}
\hline Microorganism (strain) & Faba bean & Sample coding \\
\hline Kefir type B -heterofermentative culture & - & $\mathrm{K}$ \\
$\mathrm{K}+$ Lactobacillus acidophilus (B4495) & - & $\mathrm{KP} 1$ \\
$\mathrm{~K}+$ Bifidobacteriumlactis(41405) & - & $\mathrm{KP} 2$ \\
$\mathrm{~K}+$ Lactobacillus acidophilus + Bifidobacteriumlactis & - & $\mathrm{KP} 12$ \\
$\mathrm{~K}$ & + & $\mathrm{KF}$ \\
$\mathrm{K}+$ Lactobacillus acidophilus $(\mathrm{B} 4495)$ & + & $\mathrm{KP} 1 \mathrm{~F}$ \\
$\mathrm{~K}+$ Bifidobacteriumlactis(41405) & + & $\mathrm{KP} 2 \mathrm{~F}$ \\
$\mathrm{~K}+$ Lactobacillus acidophilus + Bifidobacteriumlactis & + & $\mathrm{KP} 12 \mathrm{~F}$
\end{tabular}

$(+) ;(-)$ with and without faba bean supplementation, respectively.

\subsection{Microbiological Analyses}

Eight different kefir were prepared with and without faba bean and different probiotic strains (Table 1). Once fermentation was complete, kefir samples were stored at $4{ }^{\circ} \mathrm{C}$, and bacteria lenumerations were carried out once a week for a total of 4 weeks $(1,7,14,21$, and 28 days)in triplicate for each batch at different dilutions (four serial dilutions of 1/10). From each dilution, a $5 \mu \mathrm{L}$ portion was plated on MRS agar (Sigma Aldrich Canada Ltd., Oakville, Ontario) as described previously (Espírito Santo et al., 2010), and incubated at $40{ }^{\circ} \mathrm{C}$ and colony counts were converted to $\log \mathrm{CFU} / \mathrm{mL}$.

\section{$2.3 \mathrm{pH}$ and Total Titratable Acidity (TTA)}

The $\mathrm{pH}$ of the kefir samples was measured using a Denver Instrument UB-5 pH meter (Denver Instrument, Bohemia, New York, USA). Titratable acidity was determined by titrating a mixture of kefir and sterile water $(1: 9 \mathrm{v} / \mathrm{v})$ with $0.1 \mathrm{~N} \mathrm{NaOH}$ using $0.1 \%(\mathrm{w} / \mathrm{v})$ phenolphthalein indicator. The TTA values were reported as $\%$ lactic acid equivalent.

\subsection{Statistical Analyses}

Three determinations were made for all assays. Two-way repeated-measures ANOVA (probiotics treatment $\mathrm{x}$ faba bean treatment) were performed with Graph Pad Prism (Version 5, Graph Pad Software, La Jolla, CA). Cluster analysis was performed using SYSTAT 12 version 12.02 for Windows, (SYSTAT Software Inc., San Jose, CA) using complete linkage hierarchical clustering with the Euclidean distance as similarity measure.

\section{Results and Discussion}

\subsection{Microbial Viability}

Microorganisms were enumerated during kefir storage at $4{ }^{\circ} \mathrm{C}$ for 28 days (Figure 1). During this period, viable cell counts of kefir increased (initial count of $6.8 \log \mathrm{CFU} / \mathrm{mL}$ ) during the first week (day 1 to 7) and remained constant until day 21 and decreased thereafter with an average $87 \%$ survival rate. This trend, similar to a recent study on Brazilian kefir (Leite et al., 2013) has been ascribed to the behavior of the different microbial community, particularly the lactic acid and acetic acid bacteria. Both bacterial counts increased initially, thereafter the lactic acid bacteria counts remained constant, whereas those of acetic acid decreased at $672 \mathrm{~h}$ storage (Leite et al., 2013). Probiotics increased (3-6 \%) the microbial viability of kefir, although differences in the effects of the individual strains (Lb. acidophilus or B. lactis) and their co-culture (KP12, Table 1) were minimal. Kefir containing B. lactis showed the highest increase (11\%) in viable cell count during the first week of storage. Faba bean supplementation generally increased cell counts of kefir (Figure 1), with the highest increase (9-26\%, for days 1 and 28, respectively) relative to control kefir (without probiotic/s). Kefir with probiotics containing faba bean had higher (6-23\%) viable cell counts compared to their relative unsupplemented controls (KP1, KP2, KP12) with minimal differences between bacterial strains and their co-cultures. Viable cell count increased initially for the first week (days 1 to 7) and remained constant thereafter until the end of the 4 week storage for faba bean supplemented kefir. This suggests that faba bean supplementation maintains cell viability during extended kefir storage probably due to diverse microorganisms and/or complex relationships between microbial communities. All kefir maintained probiotic activity for therapeutic activity with a minimum of $10^{7}$ and $10^{6} \mathrm{CFU} / \mathrm{mL}$ for Lb. acidophilus and B. lactis, respectively according to the International Dairy 
Federation, present as adjunct cultures in fermented products such as yogurt (Champagne \& Gardner, 2005). Furthermore, viable bacterial count was retained at an acceptable range throughout the manufacture, incorporation and storage of faba bean kefir.
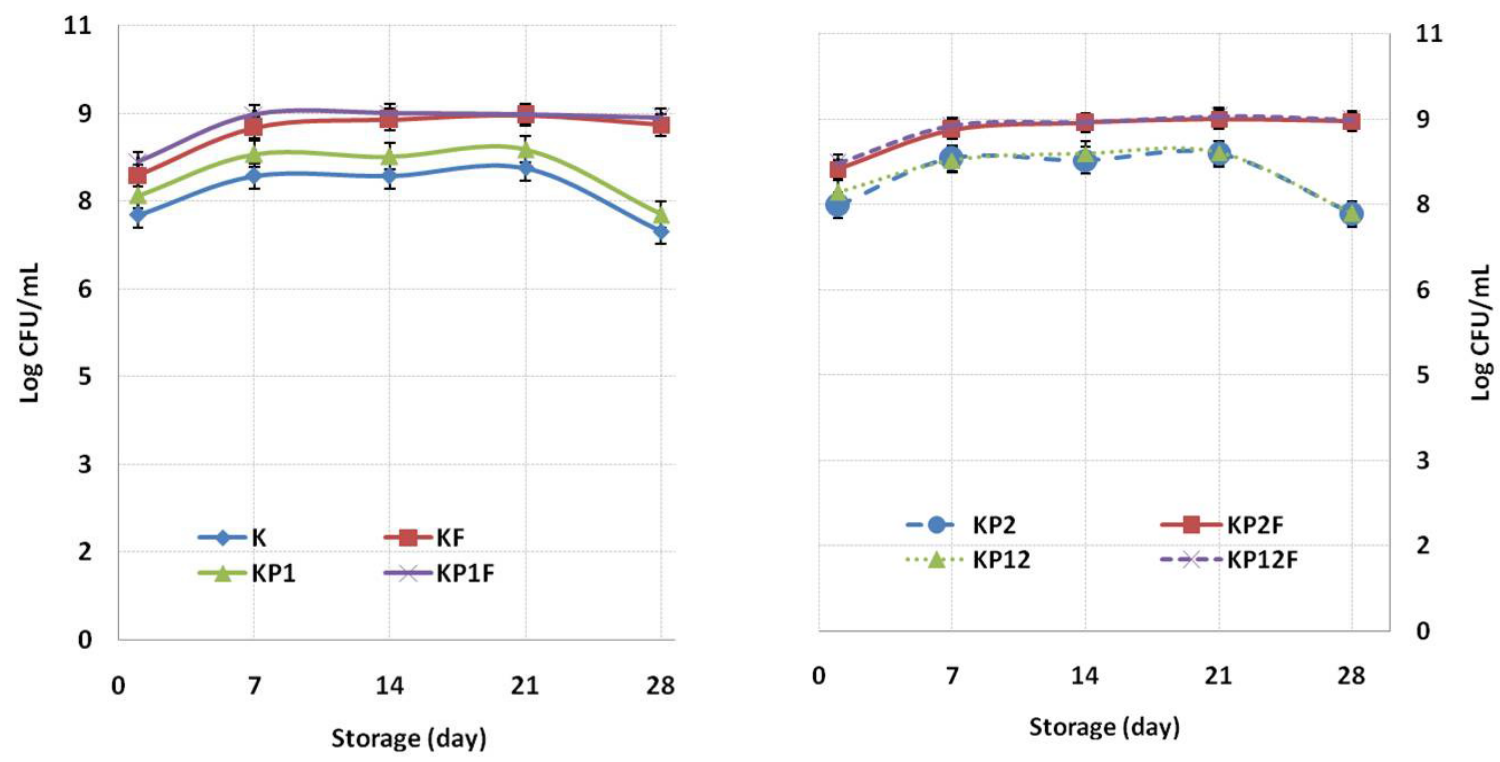

Figure 1. Viable cell counts of control and faba bean enriched kefir during storage

\subsection{Total Titratable Acidity (TTA) and $\mathrm{pH}$}

Titratable acidity, a measure of lactic acid concentration ranged from 0.38 to $0.7 \%$ among the samples at day 1 for kefir with B. lactis and faba bean supplemented kefir with Lb. acidophilus, respectively (Figure 2). At day 7 , lactic acid concentration increased considerably by $19 \%$ (KP12, for kefir with probiotic co-culture $L b$. acidophilus- B. lactis) to $59 \%$ (KP2, for kefir with B. lactis), followed by only moderate increase up to 21 days and a reduction after 4 weeks of kefir storage at $4{ }^{\circ} \mathrm{C}$ with or without faba bean. B. lactis increased titratable acidity favorably, whereas $L b$. acidophilus had an antagonistic effect in the probiotic co-culture. Higher levels $(1.5-1.9 \mathrm{x} ; p<0.05)$ of lactic acid were observed in kefir containing faba bean compared with their respective controls without bean. Furthermore, lactic acid content of faba bean supplemented kefir, increased linearly $\left(\mathrm{r}^{2} \geq\right.$ 0.94 ) from day 1 to 21 , (except $\mathrm{KP} 12 \mathrm{~F}, \mathrm{r}^{2}=0.89$ ) suggesting minimum syneresis during storage where appropriate lactic acid concentration is required to ensure proper flavor (Karleskind, Laye, Halpin, \& Morr, 1991; Granata \& Morr, 1996). Our results are similar to those observed with açai supplemented yoghurt (Espírito Santo et al., 2010), and contrast with the lower lactic acid concentration of soymilk kefir compared to milk kefir (Liu \& Lin, 2000). 


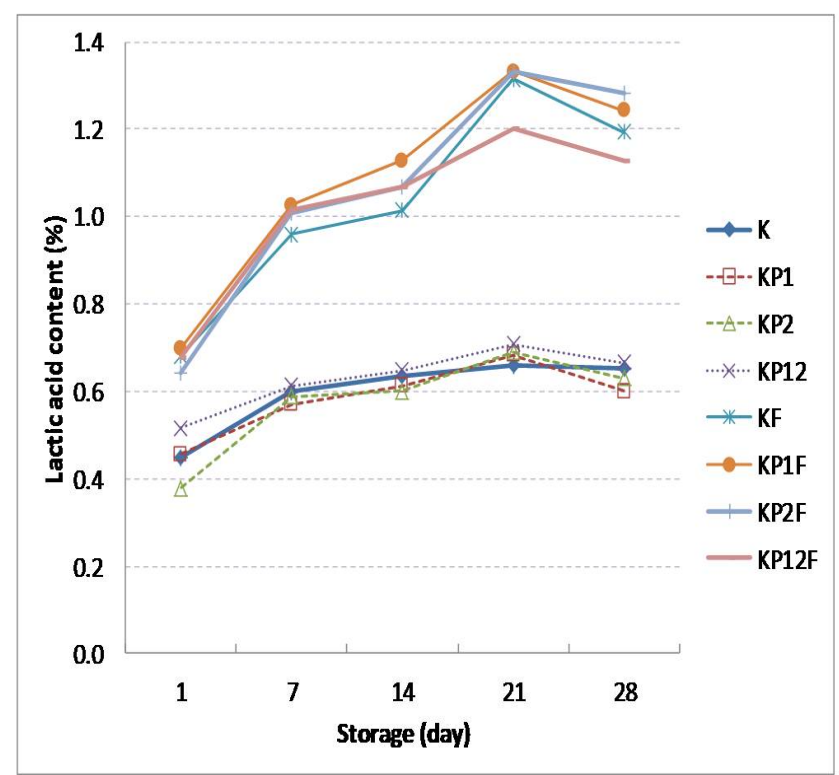

Figure 2. Total titratable acidity (\% lactic acid) of control and faba bean enriched kefir during storage

The initial $\mathrm{pH}$ of milk 6.8 , once inoculated gradually decreased to 3.94 , signifying complete fermentation thereby representing day 0 . At day $1, \mathrm{pH}$ varied from 3.66 to 3.72 and decreased linearly $\left(\mathrm{r}^{2}=\geq 0.97\right)$, to 3.13 or 3.48 after 28 days at $4{ }^{\circ} \mathrm{C}$ (Figure 3). Similar progressive $\mathrm{pH}$ reduction $(6.55-4.31)$ has been reported in kefir as a consequence of organic production (Leite et al., 2013) that contribute to the flavor, aroma and preservation of fermented dairy products. The faba bean containing kefir had lower $\mathrm{pH}(p<0.05)$, twice the reduction rate, in relation to the corresponding controls without bean (Figure 3). This suggests that $\mathrm{pH}$ reduction was favored by faba bean component/s, probably abundant, easily fermentable polysaccharides without affecting the fermentative capacity of the microflora. According to Teixeira et al. (2012), Lb. reuteri grew rapidly in faba bean flour evidenced by fermentation and reduction in sucrose, raffinose, stachyose and verbascose thereby resulting in $\mathrm{pH}$ decrease after $8 \mathrm{~h}$. Commercial bacterial inoculum, similar to those used in this study, reduced $\mathrm{pH}$ during in vitro fermentation of bean polysaccharides reflected in the acetic acid production (Campos-Vega et al., 2012). Furthermore, $\mathrm{pH}$ differences were insignificant within the kefir controls (unsupplemented) and faba bean supplemented groups.

The comparison of bacterial counts with total titratable acid and $\mathrm{pH}$ revealed strong correlation (Table 2). Bacterial count was strongly and positively correlated with lactic acid content $(\mathrm{r}=0.88-0.99, p<0.005$, particularly with the strongest $(\mathrm{r} \geq 0.97, p<0.0001)$ association for bacterial count at 28 days. $\mathrm{pH}$ was inversely related to bacterial count $(\mathrm{r}=-0.86$ to $-0.99, p<0.005)$ and titratable acidity $(\mathrm{r}=-0.77$ to $-0.99, p<0.01)$ with the lowest correlation occurring at day 1 . 


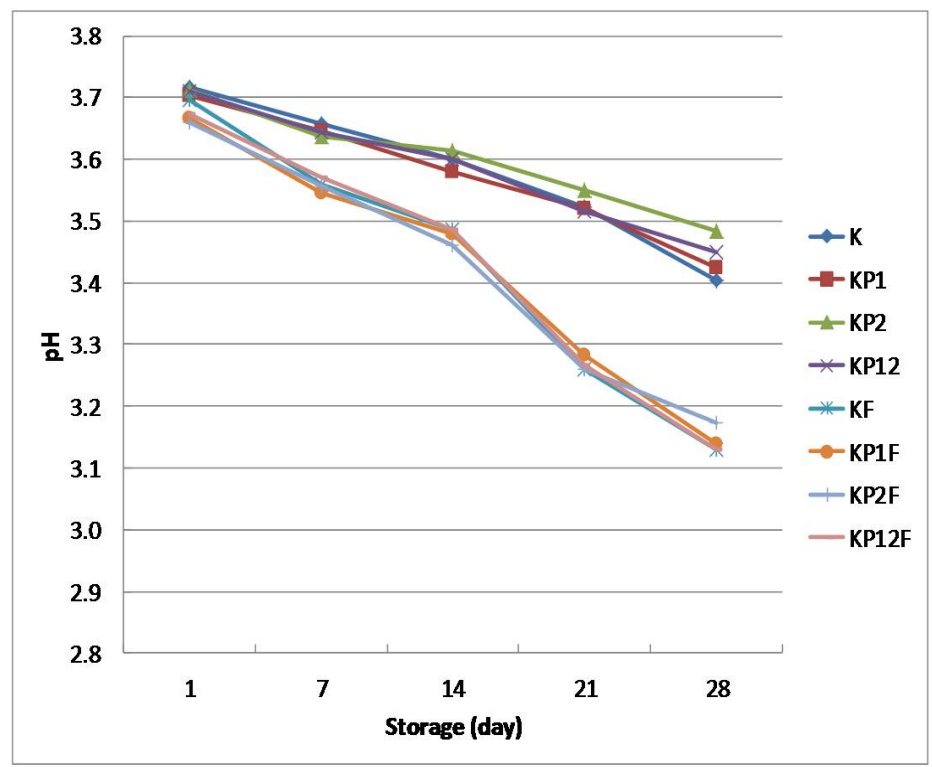

Figure 3. $\mathrm{pH}$ of control and faba bean enriched kefir during storage

Table 2. Correlation coefficients for bacterial counts (CFU), titratable acidity (TTA) and pH

\begin{tabular}{|c|c|c|c|c|c|c|c|c|c|c|c|c|c|c|}
\hline & CFU7 & CFU1 & 4 CFU21 & 1 CFU28 & TTA1 & TTA7 & TTA14 & TTA21 & TTA28 & pH1 & pH7 & pH14 & pH21 & pH28 \\
\hline CFU1 & 0.968 & 0.974 & 0.965 & $0.945^{* * *}$ & $=0.912 * * *$ & $0.917 * * *$ & * $0.919 * * *$ & * $0.893 * *$ & $0.884 * *$ & $-0.903 * *$ & $*-0.921 * *$ & $-0.902 * *$ & $-0.895 * *$ & $-0.866^{* *}$ \\
\hline CFU7 & & 0.988 & 0.984 & 0.966 & $0.889^{* *}$ & $0.932 * * *$ & $0.933 * * *$ & $* 0.932 * * *$ & $0.911 * * *$ & $-0.879 * *$ & * -0.961 & $-0.918 * * *$ & $-0.912 * * *$ & $-0.887 * *$ \\
\hline CFU14 & & & 0.993 & 0.979 & $0.922 * * *$ & $0.949 * * *$ & $0.946^{* * *}$ & $* 0.953 * * *$ & $0.938 * * *$ & $-0.861 * *$ & * -0.976 & $-0.934 * * *$ & $-0.937 * * *$ & $-0.903 * *$ \\
\hline CFU21 & & & & 0.985 & $0.909 * * *$ & $0.950 * * *$ & * $0.942 * * *$ & $* 0.951 * * *$ & $0.934 * * *$ & $-0.863 * *$ & * -0.969 & $-0.941 * * *$ & $-0.946 * * *$ & $-0.914 * *$ \\
\hline CFU28 & & & & & $0.938 * * *$ & 0.989 & 0.983 & 0.983 & 0.977 & $-0.869 * *$ & * -0.989 & -0.975 & -0.983 & $-0.962 * * *$ \\
\hline TTA1 & & & & & & $0.952 * * *$ & 0.960 & $0.942 * * *$ & $0.938 * * *$ & $-0.765 *$ & $-0.938 * *$ & $-0.932 * * *$ & -0.959 & -0.960 \\
\hline TTA7 & & & & & & & 0.998 & 0.985 & 0.988 & $-0.856^{* *}$ & * -0.982 & -0.976 & -0.989 & -0.979 \\
\hline TTA14 & & & & & & & & 0.984 & 0.987 & $-0.860 * *$ & * -0.981 & -0.976 & -0.985 & -0.979 \\
\hline TTA21 & & & & & & & & & 0.996 & $-0.824 *$ & -0.993 & -0.982 & -0.988 & -0.969 \\
\hline TTA28 & & & & & & & & & & $-0.836 * *$ & * -0.985 & -0.982 & -0.986 & -0.966 \\
\hline $\mathrm{pH} 1$ & & & & & & & & & & & $0.832 *$ & $0.884 * *$ & $0.821^{*}$ & $0.786^{*}$ \\
\hline $\mathrm{pH} 7$ & & & & & & & & & & & & 0.965 & 0.974 & $0.952 * * *$ \\
\hline pH14 & & & & & & & & & & & & & 0.985 & 0.968 \\
\hline $\mathrm{pH} 21$ & & & & & & & & & & & & & & 0.990 \\
\hline
\end{tabular}

All correlation coefficient significant at $p<0.0001$, except $* * * p<0.001, * * p<0.005$ and ${ }^{*} p<0.01$.

The dendogram (Figure 4) obtained from hierarchical cluster analysis based on the microbiological, titratable acidity and $\mathrm{pH}$ data enabled the identification of two major main clusters, corresponding to the presence or absence of faba bean supplementation, with the greatest distance $(0.65$ - often referred to $65 \%$ coefficient of similarity) between them. The clusters were further grouped into three sub clusters each, primarily based on differences of the probiotic strain with distances: minimum (0.046) between probiotic 1 and 2, moderate $(0.069)$ between probiotic 2 and the co-culture (probiotic 12), and maximum (0.206) between the control (kefir without probiotic) and the co-culture. Similar partition was maintained within the faba bean supplemented cluster with minimum, moderate and maximum distances of $0.057,0.065$, and 0.093 , respectively.

Two-way analysis of variance with faba bean and probiotics as factors confirmed the cluster analysis. Faba bean supplementation explained 53 and 64\%, whereas probiotic strains accounted for 27 and $34 \%$ of the overall 
variability in titratable acidity and microbial viability, respectively. The results were reversed for $\mathrm{pH}$ with microbial viability predominating $(69 \%)$ the overall variability and faba bean accounting for only $20 \%$.

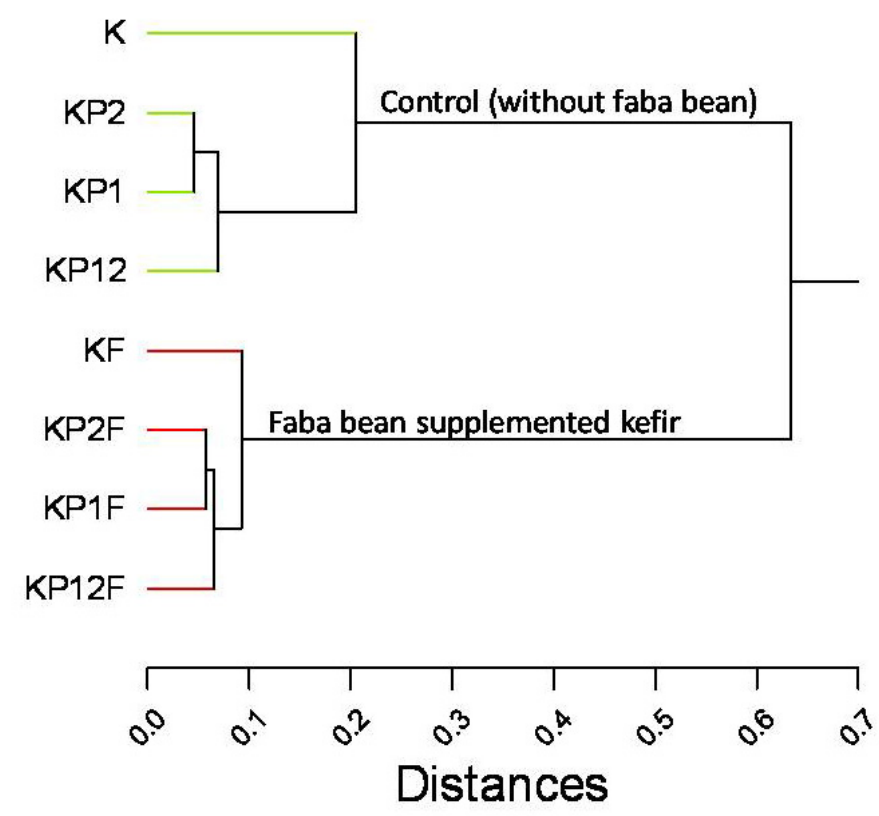

Figure 4. Dendogram of control and faba bean enriched kefir during storage

The synergy factor analysis based on the procedure of Cortina-Borja et al. (2009) showed that the probiotic co-culture (Lb. Acidophilus and B. lactis) had additive effect $(\mathrm{SF}=1.0-1.03 ; p=0.05)$ on viable cellcounts and $\mathrm{pH}$ of kefir. However, an antagonistic effect $(\mathrm{SF}=0.73-0.90(<1) ; p=0.05)$ was observed for titratable acidity comparing faba bean supplemented and regular kefir as control. This antagonistic effect $(\mathrm{SF}=0.74)$ for titratable acidity of the co-culture was also obtained with green lentil supplemented yogurt only at 7 day storage (Agil et al., 2013) using the same calculation procedure. However, the probiotic co-culture showed synergistic ( $\mathrm{SF}=1.24$ and 1.27 for 14 and 21 days, respectively) or additive effect ( $\mathrm{SF}=1.02$ for 28 days storage) for titratable acidity of green lentil yogurt. The interaction between $L b$. acidophilus and B. lactis probablyhad a bufferingeffect in co-culture thatwas minimal or absent in the individual strains. Thus faba bean enables beneficial bacteria to thrive in the presence of either single probiotic or their co-culture during extended storage for 28 days and differs functionally from green lentil. Probiotic combinations have proven effective in treating gastrointestinal disorders, for example, necrotizing enterocolitis in preterm infants (Jacobs et al., 2013) and antibiotic-associated diarrhea in hospital patients (Ouwehand et al., 2013).

Faba bean supplementation at $4 \%$ stimulated bifidogenic microbial growth, increased titratable acidity and reduced $\mathrm{pH}$ during kefir storage for 28 days. This may partly be due to the presence of the highly fermentable raffinose family oligosaccharides $(0.20,0.85$, and $3.05 \%$ [dry matter] of raffinose, stachyose and verbascose, respectively (Quemener, 1988). Furthermore, the faba bean oligosaccharides elicit high microbial glucosidase and galactosidase activities enabling the metabolism of the raffinose family of oligosaccharides in rats (Juśkiewicz et al., 2006). This galactosidase activity contributes to the fast conversion of the raffinose family oligosaccharides resulting in their rapid decrease and acetate formation (i.e., reduced $\mathrm{pH}$ ) during fermentation with $L$ b. reuteri (Teixera et al., 2012). Similar increase in acidity and bacterial (Lactococcus lactis) count has been reported in soymilk kefir containing 3\% $(\mathrm{w} / \mathrm{w})$ soy fiber resulting in increased (elevated) viscosity and firmness and reduced syneresis (Baú, Garcia, \& Ida, 2013). Other faba bean components such as the antimicrobial peptide fabatin may have contributed in stimulating beneficial microbial growth. Fabatin and the acid extract of faba bean flour exhibit strong activity against Pseudomonas aeruginosa at low $(1 \mu \mathrm{g} / \mathrm{mL})$ concentration, and moderate activity against Escherichia coli K12 and Enterococcus hirae (Zhang \& Lewis, 1997). E. coli is further challenged by faba bean in animal intestine thereby reducing/preventing gastrointestinal problems affecting gut health of post weaned piglets (Van der Meulen, Panneman, \& Jansman, 2010). Faba bean is also a source of $\gamma$-aminobutyric acid (GABA) at approximately $0.05 \mathrm{mg} / \mathrm{g}$ in raw seeds (Li et al., 2010), and in 
addition, GABA production increases during kefir storage. GABA (10 mg daily) lowers blood pressure in mild hypertensive when consumed in fermented milk over a 12-week period (Grønnevik, Falstad, \& Narvhus, 2011). GABA, a neurotransmitter is believed to have a calming, relaxing effect on the nervous system and is therefore used as a popular relaxation and anti-stress ingredient (Ohr, 2013).

The kefir characteristics (elevated microbial growth and acidity and reduced $\mathrm{pH}$ ) improved by faba bean supplementation during storage can enhance the bifidogenic/probiotic effect such as resistance to gastrointestinal pathogen infection, stimulate protein digestion and contribute beneficially to a unique taste, aroma and flavor. Results of the present study provide an important alternative use of faba beans with probiobic fermentation as the basis for functional food design. Faba bean supplemented kefir is a low cost initiative to increase dairy product consumption expected to rise $25 \%$ by 2025 in the developing world according to the recent Food and Agriculture Organization (FAO, 2013) scope to raise nutrition among poorest people.

\section{Conclusions}

This study compared the extended storage of faba bean enriched kefir with corresponding unsupplemented controls with and without individual probiotic and their co-culture. Faba bean flour stimulated microbial growth, increased acidity and reduced $\mathrm{pH}$ during kefir cold storage. Furthermore, faba bean exerts a distinct antagonistic effect on titratable acidity of the probiotic co-culture (Lb. acidophilus and B. lactis) enabling its prebiotic activity to withstand storage, maintaining probiotic stability and potentiallyreducewaste. Kefir presents a low-cost, diet based solution to enhance the consumption of faba bean flour with minimal processing simultaneously rendering its nutrients in a replete state that can physiologically and optimally benefit human health.

\section{References}

Agil, R., Gaget, A., Gliwa, J., Avis, T. J., Willmore, W. G., \& Hosseinian, F. (2013). Lentils enhance probiotic growth in yogurt and provide added benefit of antioxidant protection. LWT-Food Science and Technology, 50(1), 45-49. http://dx.doi.org/10.1016/j.lwt.2012.07.032

Alexandratos, N., \& Bruinsma, J. (2012). World agriculture towards 2030/2050: the 2012 revision. ESA Working paper No. 12-03. Rome: Food and Agriculture Organization.

Baú, T. R., Garcia, S., \& Ida, E. L. (2013). Optimization of a fermented soy product formulation with a kefir culture and fiber using a simplex-centroid mixture design. International Journal of Food Science and Nutrition, 64(8), 929-935. http://dx.doi.org/10.3109/09637486.2013.816935

Boudjou, S., Oomah, B. D., Zaidi, F., \& Hosseinian, F. (2013). Phenolics content and antioxidant and anti-inflammatoryactivities of legume fractions. Food Chemistry, 138, 1543-1550. http://dx.doi.org/10.1016/j.foodchem.2012.11.108

Campos-Vega, R., Garcia-Gasca, T., Guevara-Gonzalez, R. G., Ramos-Gómez, M., Oomah, B. D., \& Loarca-Pina, G. (2012). Human gut flore-fermented non digestible fraction from cooked bean (Phaseolus vulgaris L.) modifies protein expression associated with apoptosis, cell cycle arrest and proliferation in human adenocarcinoma colon cancer cells. Journal of Agricultural and Food Chemistry, 60(51), 12443-12450. http://dx.doi.org/10.1021/jf303940r

Champagne, C. P., \& Gardner, N. J. (2005). Challenges in the addition of probiotic cultures to foods. Critical Reviews in Food Science and Nutrition, 45, 61-84.

Cortina-Borja, M., Smith, A. D., Combarros, O., \& Lehmann, D. J. (2009). The synergy factor: a statistic to measure interactions in complex diseases. BMC Research Notes, 2, 105.http://dx.doi.org/10.1186/1756-0500-2-105

Espírito Santo, A. P., Silva, R. C., Soares, F. A. S. M., Anjos, D., Gioielli, L. A., \& Oliveira, M. N. (2010). Açai pulp addition improves fatty acid profile and probiotic viability in yoghurt. International Dairy Journal, 20, 415-422. http://dx.doi.org/10.1016/j.idairyj.2010.01.002

FAO. (2013). Milk and Dairy Products in Human Nutrition. In E. Muehlhoff, A. Bennett \& D. McMahon (Eds.), (p. 376), Rome. Retrieved 29 December, 2013, from http://www.fao.org/docrep/018/i3396e/i3396e.pdf

Granata, L.A., \&Morr, C. V. (1996). Improved acid, flavor and volatile compound production in a high-protein and fiber soymilk yogurt-like product. Journal of Food Science, 61, 331-336. http://dx.doi.org/10.1111/j.1365-2621.1996.tb14188.x

Grønnevik, H., Falstad, M., \& Narvhus, J. A. (2011). Microbiological and chemical properties of Norwegian kefir during storage. International Dairy Journal, 21(9), 601-606. 
http://dx.doi.org/10.1016/j.idairyj.2011.01.001

Isibashi, N., \& Shimamura, S. (1993). Bifidobacteria: research and development in Japan. Food Technology, 47(6), 126-136.

Iwana, H., Masuda, H., Fujisawa, T., Suzuki, H., \& Mitsuoka, T. (1993). Isolation of Bifidobacterium spp. in commercial yoghurts sold in Europe. Bifidobacteria Microflora, 12, 39-45. http://dx.doi.org/10.12938/bifidus1982.12.1_39

Jacobs, S. E., Tobin, J. M., Opie, G. F., Donath, S., Tabrizi, S. N., Pirotta, Morley, C. J., \& Garland, S. M. (2013). Probiotic effects on late-onset sepsis in very preterm infants: A randomized controlled trial. Pediatrics, 132(6), 1055-1062. http://dx.doi.org/10.1542/peds.2013-1339

Jansman, A. J. M., van Baal, J., van der Meulen, J., \& Smits, M. A. (2012). Effects of faba bean and faba bean hulls on expression of selected genes in the small intestine of piglets. Journal of Animal Science, 90 (Supplement 4), 161-163. http://dx.doi.org/10.2527/jas.53848

Juśkiewicz, J., Wróblewska, M., Fertykowski, S., Zduńczyk, Z., Brzuzan, Ł., \& Godycka-Kłos, I. (2006). Effect of faba bean seeds and their fractions on rat caecum physiology. Veterinarijair Zootechnika, 35(57), 67-71.

Karleskind, D., Laye, I., Halpin, E., \& Morr, C. V. (1991). Improving acid production in soy-based yogurt by adding cheese whey proteins and mineral salts. Journal of Food Science, 55, 999-1001. http://dx.doi.org/10.1111/j.1365-2621.1991.tb14626.x

Keats, S., \& Wiggins, S. (2014). Future Diets Implications for Agriculture and Food Prices. Overseas Development Institute Report.117 pp., London, UK. Retrieved from http://www.odi.org.uk/sites/odi.org.uk/files/odi-assets/publications-opinion-files/8773.pdf

Leite, A. M. O., Leite, D. C. A., Del Aguila, E. M., Alvares, T. S., Peixoto, R. S., Miguel, M. A. L.,... Paschoain, V. M. F. (2013). Microbiological and chemicalcharacteristics of Braziliankefirduring fermentation and storageprocesses. Journal of Dairy Science, 96, 4149-4159. http://dx.doi.org/10.3168/jds.2012-6263

Li, Y., Bai, Q., Jin, X., Wen, H., \& Gu, Z. (2010). Effects of cultivar conditions on $\gamma$-aminobutyric acid accumulation in germinated fava beans (Vicia faba L.). Journal of the Science of Food and Agriculture, 90, 52-57. http://dx.doi.org/10.1002/jsfa.3778

Link, W., Hanafy, M., Malencia, N., Jacobsen, H-J., \& Jelenić, S. (2008). Faba bean. In C. Kole \& T. C. Hall (Eds.), Compendium of Transgenic Crop Plants: Part 3. Transgenic Legume Grains and Forages (pp. 71-88). Oxfordshire, UK: Blackwell Publishing Ltd.

Liu, J-R., \& Lin, C-W. (2000). Production of kefir from soymilk with or without added glucose, lactose or sucrose. Journal of Food Science, 65(4), 716-719. http://dx.doi.org/10.1111/j.1365-2621.2000.tb16078.x

Mellentin, J. (2013). 12 Key trends in food, nutrition \& health 2014. New Nutrition Business, 19(2), 102. London, UK.

Ohr, L. M. (2013). Pouring on a state of peace and calm. Food Technology, 67(12), 81-82.

Ouwehand, A. C., DongLian, C., Weijian, X., Stewart, M., Ni, J., Stewart, T., \& Miller, L. E. (2014). Probiotics reduce symptoms of antibiotic use in a hospital setting: A randomized dose response study. Vaccine, 32(4), 458-463. http://dx.doi.org/10.1016/j.vaccine.2013.11.053

Quemener, B. (1988). Improvements in the high-pressure liquid chromatographic determination of amino sugars and $\alpha$-galactosides in faba bean, lupine, and pea. Journal of Agricultural and Food Chemistry, 36(4), 754-759. http://dx.doi.org/10.1021/jf00082a020

Saad, N., Delattre, C., Urdaci, M., Schmitter, J. M., \& Bressollier, P. (2013). An overview of the last advances in probiotic and prebiotic field. LWT-Food Science and Technology, 50, 1-16. http://dx.doi.org/10.1016/j.lwt.2012.05.014

Teixeira, J. S., McNeill,V., \& Gänzle, M. G. (2012). Levansucrase and sucrose phoshorylase contribute to raffinose, stachyose, and verbascose metabolism by lactobacilli. Food Microbiology, 31(2), 278-284. http://dx.doi.org/10.1016/j.fm.2012.03.003

Van der Meulen, J., Panneman, H., \& Jansman, A. J. M. (2010). Effect of pea, pea hulls, faba beans and faba bean hulls on the ileal microbial composition in weaned piglets.Livestock Science, 133(1), 135-137. http://dx.doi.org/10.1016/j.livsci.2010.06.045

Zare, F., Boye, J. I., Champagne, C. P., Orsat, V., \& Simpson, B. K. (2013). Probiotic Milk Supplementation with 
Pea Flour: Microbial and Physical Properties. Food and Bioprocess Technology, 1-11.

Zare, F., Boye, J. I., Orsat, V., Champagne, C., \& Simpson, B. K. (2011). Microbial, physical and sensory properties of yogurt supplemented with lentil flour. Food Research International, 44(8), 2482-2488. http://dx.doi.org/10.1016/j.foodres.2011.01.002

Zare, F., Champagne, C. P., Simpson, B. K., Orsat, V., \& Boye, J. I. (2012). Effect of the addition of pulse ingredients to milk on acid production by probiotic and yoghurt starter cultures. LWT-Food Science and Technology, 45(2), 155-160. http://dx.doi.org/10.1016/j.lwt.2011.08.012

Zhang, Y., \& Lewis, K. (1997). Fabatins: new antimicrobial plant peptide. FEMS Microbiology Letters, 149, 59-64. http://dx.doi.org/10.1111/j.1574-6968.1997.tb10308.x

\section{Copyrights}

Copyright for this article is retained by the author(s), with first publication rights granted to the journal.

This is an open-access article distributed under the terms and conditions of the Creative Commons Attribution license (http://creativecommons.org/licenses/by/3.0/). 